\title{
Liquid Bio-Fertilizers and Sustainable Forestry: A Mini Review
}

\author{
1Division of Basic Sciences \& Humanities, India \\ 2Department of Environmental Science, Govt. Degree College, India \\ 3Department of Botany, Govt. Degree College, India \\ 4Division of Agronomy, FOA / RRS, India
}

Malik Asif ${ }^{1 *}$, Shazia Lone ${ }^{2}$, FA Lone ${ }^{3}$, MA Malik ${ }^{1}$, ZM Dar ${ }^{1}$, Amjad M ${ }^{4}$ and Saima Shafi ${ }^{1}$

Submission: March 25, 2018; Published: April 23, 2018

"Corresponding author: Malik Asif, Division of Basic Sciences \& Humanities, FOA/RRS, Wadura, SKUAST, India, Email: drasif_skuast@yahoo.com

\begin{abstract}
Liquid biofertilizers have gained extensive importance worldwide. These are naturally occurring bacteria that actively colonize the plant roots and improve plant growth. Plants inoculated with some potential liquid biofertilizer strains exhibit improved biomass production. It has been observed that liquid bio-fertilizers exert their growth promoting effects on plants by utilizing a number of mechanisms. Taken as an example, inoculants improve legume growth due to their potential involvement in nitrogen fixation. Supply of nutrients like phosphorous, copper, iron, sulphur etc. is enhanced in the plants having rhizosphere enriched with microbial inoculants. These also act as bio-control agents by imposing their negative effects on the growth of disease causing bacteria, fungi and help in controlling insect pests. The research on liquid biofertilizers has been on rise for the past few decades and several products containing live strains have been commercialized for their use in forestry. The more emphasis of scientists on these live fertilizers is due to the fact that these could only be the best alternative for the chemical products being utilized on a wide scale for getting improved yield. These chemical products are known to add to the pollutants prevailing in our environment. Therefore, this mini review focuses on the potential of liquid biofertilizers that make them suitable alternative for chemical products being extensively exploited in Sustainable forestry practices.
\end{abstract}

Keywords: Forests; Liquid bio-fertilizers; Soil; Health; Sustainable; Environment

\section{Introduction}

In tropical countries like India, there is a problem of nitrogen deficiency and phosphorous non-availability especially in degraded or stressed soils. In order to overcome these deficiencies, chemical fertilizers are being used. However, indiscriminate use of chemical fertilizers regardless of climatic, soil and other factors has affected the environmental quality and soil ecosystem. There are many reports that show adverse effects of inorganic fertilizers on both beneficial micro flora and micro fauna as well as their activities (Zargar et al., 1999). Like other soils forest soils are also facing acute shortage of essential nutrients mainly due to continuous erosion. Moreover fertilization of forest soils is not easy as forests occupy remote, less accessible and less fertile lands. It is therefore feasible to make use of native microbial inoculants as natural nutrient mobilizers for better growth, development and survival of tree species as a substitute for inorganic fertilizers. Simultaneously, the use of Liquid bio-fertilizers will reduce the use of synthetic fertilizers which in turn decreases the cost of cultivation and ill effects on human health and soil ecosystem, besides improving the growth of plants significantly. Thus, development and establishment of suitable microbial strains is essential to improve the survival and quality of planting stock so as to undertake national developmental Programmes of afforestation, reforestation, wasteland-reclamation and social forestry successfully. Dosage and time of application of bio-fertilizers varies from species to species. It has seen that biofertilizers can be applied through seed, inoculation, seedling dip method and broadcasting in the main forest nursery through mixing with farm yard manure/ compost.

\section{Conclusion}

Keeping in view the above given brief discussion on different aspects of liquid bio-fertilizers, it is now clear that the chemical fertilization can be minimized to a great extent using ecofriendly liquid bio-fertilizers. The use of these bio-inoculants is an attractive as well as economic approach for sustainable forestry. The commercialization of microbial strains as fertilizers should be emphasized. There is need to create awareness among 
foresters/farmers about the potential benefits that could be obtained using these microorganisms rather than focusing on cost ineffective approaches based on the use of chemical fertilizers which have polluted the important ecosystems operating on earth. Production of quality planting stock has a great demand around the whole globe.

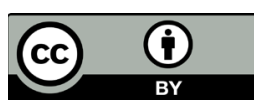

This work is licensed under Creative Commons Attribution 4.0 License DOI: 10.19080/ARTOAJ.2018.15.555958
Your next submission with Juniper Publishers will reach you the below assets

- Quality Editorial service

- Swift Peer Review

- Reprints availability

- E-prints Service

- Manuscript Podcast for convenient understanding

- Global attainment for your research

- Manuscript accessibility in different formats

( Pdf, E-pub, Full Text, Audio)

- Unceasing customer service

Track the below URL for one-step submission https://juniperpublishers.com/online-submission.php 